JUURNAL

of Health Inequalities

\title{
Hundred years of cigarette smoking in Poland: three phases of the tobacco epidemic
}

\author{
Witold A. Zatoński ${ }^{1,2}$, Mateusz Zatoński ${ }^{1}$, Kinga Janik-Koncewicz ${ }^{1}$ and the HPF team* \\ *HPF team: Katarzyna Połtyn-Zaradna², Katarzyna Wijatkowska', Arlen Marciniak' \\ ${ }^{1}$ Health Promotion Foundation, Nadarzyn, Poland \\ ${ }^{2}$ Medical University, Wrocław, Poland
}

\begin{abstract}
After the World War II Poland experienced a rapid growth of cigarette consumption. Between 1949 and 1980 , tobacco sales increased from 21.8 billion cigarettes per annum to 94.2 billion. By the 1970s cigarette production, per capita sales, and smoking prevalence among Poles aged 15+ were among the highest in the world. The tobacco industry became a strategic branch of the economy. By the early 1980s circa 15 million Poles smoked (10.5 million males and 4.5 million females). This prolonged exposition to tobacco smoke after several decades led to an explosion of tobacco-related diseases.

Between 1980 and 2000 Poland first experienced stagnation in smoking rates, and then a sustained decline in both sexes. This has been attributed to the collapse of the tobacco industry in the 1980s, and the intervention programmes stemming from the Polish Anti-tobacco Law of 1995, as well as the activity of pro-health civil society groups and medical associations.

Smoking prevalence in Poland declined between 1970s and 2014 from $73 \%$ to $28 \%$ among men and from $30 \%$ to $19 \%$ in women. The annual decline rates in Poland in this period belonged to the fastest in the world. This positive trend led to the curbing, and later fall in rates of tobacco-related diseases. In the years 1990-2015 lung cancer mortality rates among middle-aged men (35-54 years) declined from 60/100,000 to 20/100,000 and in female population between 2005 and 2015 from 15/100,000 to 11/100,000.
\end{abstract}

KEY WORDS: tobacco, consumption per capita, smoking prevalence, Poland.

ADDRESS FOR CORRESPONDENCE: Witold A. Zatoński, Professor of Medicine, Health Promotion Foundation,

51 Mszczonowska Street, 05-830 Nadarzyn, Poland, phone: +48 2237800 22, e-mail: wazatonski@promocjazdrowia.pl

\section{INTRODUCTION}

Smoking has historically been, and continues to be, one of the key factors shaping the health of adult Poles. The aim of this article is to document and analyse cigarette sales and per capita consumption rates between 19232015 , and the prevalence and epidemiology of smoking in both sexes between 1974 and 2015. Data suggest that the hundred years of cigarette smoking in Poland can be divided into three main periods: first, a slow increase in smoking from a very low level in the period before the World War II, second, an explosion of cigarette consumption, especially among men, after the Second World War, and third, a rapid decline in smoking rates in the 1990s. This paper discusses these developments.

\section{MATERIAL AND METHODS}

Smoking statistics for Poland are relatively comprehensive. This article is based on two principal sources of data - sales and per capita consumption statistics between 1923 and 2015, and smoking prevalence and socio-demographic of statistics from 1974-2015 [1-27].

\section{STATE SALE STATISTICS}

Data on cigarette sales in Poland between 1923 and 1989 were derived from the data of the Central Statistical Office of Poland [9, 14, 16, 18, 19, 21, 23, 24, 26, 28, 29]. These data are accurate, because until 1989 tobacco production, import, and sale were managed almost exclusively by the state. The state data after 1989 are less accurate, 
also because the newly privatised tobacco companies disclosed them rather reluctantly for tax-related reasons [30].

\section{SMOKING PREVALENCE STATISTICS}

Smoking prevalence statistics were drawn from research conducted by the Maria Skłodowska-Curie Memorial Cancer Center and Institute of Oncology (Warsaw Cancer Centre), with two exceptions. The first exception, the 1974 survey on smoking in Poland, was an inaugural study conducted by the newly-opened public opinion research centre (OBOP) [1]. The second exception was a study conducted in 2015 by the Chief Sanitary Inspectorate [25]. Among the studies conducted by the Warsaw Cancer Centre, the first was carried out by Maria Jokiel in 1976 [2]. The studies conducted in the years 1982-2014 were carried out, developed, and published by the Warsaw Cancer Centre's Division of
This article is dedicated to the eminent British epidemiologist Sir Richard Peto. He was one of the first scientist to demonstrate the enormous burden of smoking-attributable mortality in Poland. His work allowed tobacco control to become a political priority in the country. Peto's continuous guidance and support helped Polish anti-tobacco advocates to develop pioneering research and intervention programmes in the 1990s.
[3]. By 19824.5 million Polish women smoked [3, 16]. However, this figure concealed the significant differences between the different age groups/births cohort. In the oldest age cohort, 60+ (born before 1916) smoking prevalence in 1976 was around 5\%. Among women aged 40-59 (cohort born between 1917-1936), it stood at $20 \%$. In age groups 16-39 years (birth cohort 1937-1960) smoking prevalence was around $40 \%$.

In 1982 the prevalence of smoking among women (30\%) was the highest Polish in history [3]. Circa 15 million Poles smoked (10.5 million males and 4.5 million females). Through the 1980s cigarette consumption levels remained stagnant in both sexes (Fig. 1). The proportion of young male never-smokers rose slightly while rates of smoking among women kept increasing [12].

A rapid change started in the 1990s. For the first time in Polish history, smoking Cancer Epidemiology and Prevention, led by Professor Witold Zatonski, with the collaboration of Krzysztof Przewoźniak. They were invariably based on a representative sample of the adult Polish population (15 years old and over). The three-degree, proportionally stratified, randomized sampling design has not essentially changed since the first study. All of the studies were based on the same concept, survey questionnaire, sampling methods, etc. The sample sizes were usually 1000 individuals. The response rate has always been higher than $70 \%$ (80-90\% on average). The questionnaire has changed little with time. Smoking categories were defined according to WHO recommendations [31-32]. Almost every year the studies have been prepared and conducted by the same research team from the Division of Cancer Epidemiology and Prevention and carried out by public opinion research centres. Their results were published in numerous scientific journals, books, monographs, reports, etc., in both Polish and English [1-27].

\section{RESULTS}

After the World War II Poland experienced a rapid growth of cigarette consumption. Between 1949 and 1980, tobacco sales increased from 21.8 billion cigarettes per annum to 94.2 billion. The 1976 survey showed that cigarettes accounted for more than $99 \%$ of all tobacco products used in Poland [2]. Smoking prevalence among men aged $15+$ stood at $73 \%$ with a total of 10.5 million men smoking. In the male population, there were no significant differences in smoking frequency by age group, place of residence or level of education.

The prevalence of smoking among men remained frozen since the mid-1970s. In contrast, among women it rose significantly, from $18 \%$ in 1974 to $30 \%$ in 1982 rates fell both among men and women (Fig. 2). In the male population, the decrease could be observed in all age groups, with the pace fastest among the elderly. The decline occurred among all socio-demographic groups, but was much more pronounced among those better educated, better-off and more religious [12]. In women, smoking rates fell only in the younger age groups. The reduction has been most marked in the youngest (2029) age group; over the last decade, smoking rates among women have fallen by half (Fig. 2). The greatest reduction has occurred among young, well-educated women [12].

Overall, smoking prevalence in Poland declined between the 1976 and 2014 from $73 \%$ to $28 \%$ among men and from $30 \%$ to $19 \%$ among women. This positive trend led to the curbing, and later fall in rates of tobacco-related diseases. In the years 1990-2015 lung cancer rates among middle-aged men (35-54 years) declined from $60 / 100,000$ to $20 / 100,000$ [33].

\section{DISCUSSION}

Data indicate that the history of smoking in Poland could be divided into three broad epidemiological periods. In the first period, which stretched throughout the interwar years, 1918-1939, smoking prevalence was at a low level in comparison to Western Europe, and it was increasing at a moderate pace until World War II (Fig. 2) [26, 34].

The second period began after the end of the World War II, when a rapid increase in the sale of cigarettes began in Poland, lasting until the 1980s. Cigarettes by far dominated the Polish market, and no other tobacco products became prominent [9]. By the 1970s cigarette production, per capita sales, and smoking prevalence among those aged 15+ in Poland were among the highest 

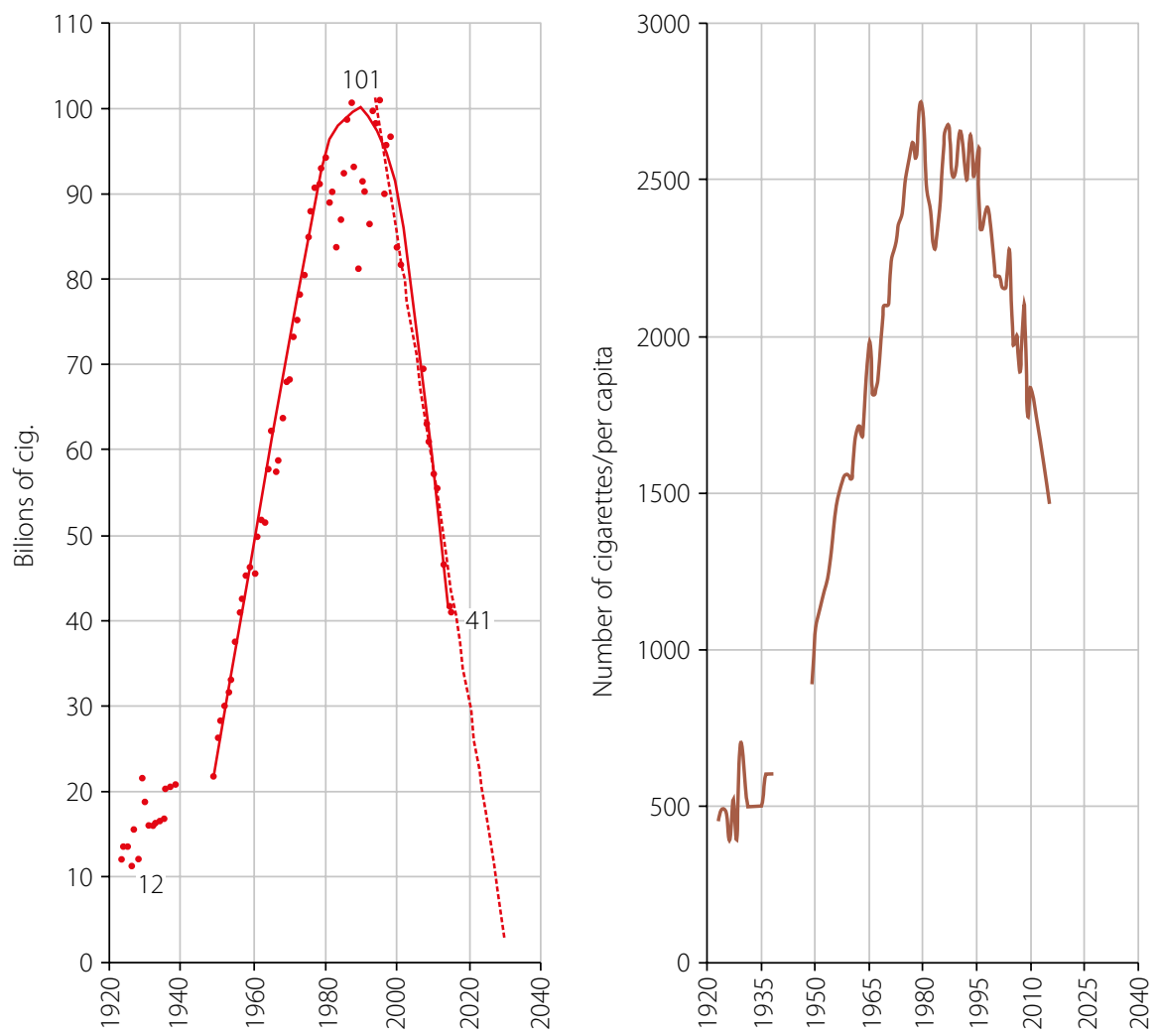

FIG. 1. Tobacco sale and tobacco consumption per capita in Poland, 1923-2015. Sources: $[9,14,16,18,19,21,23,24,26,28,29]$

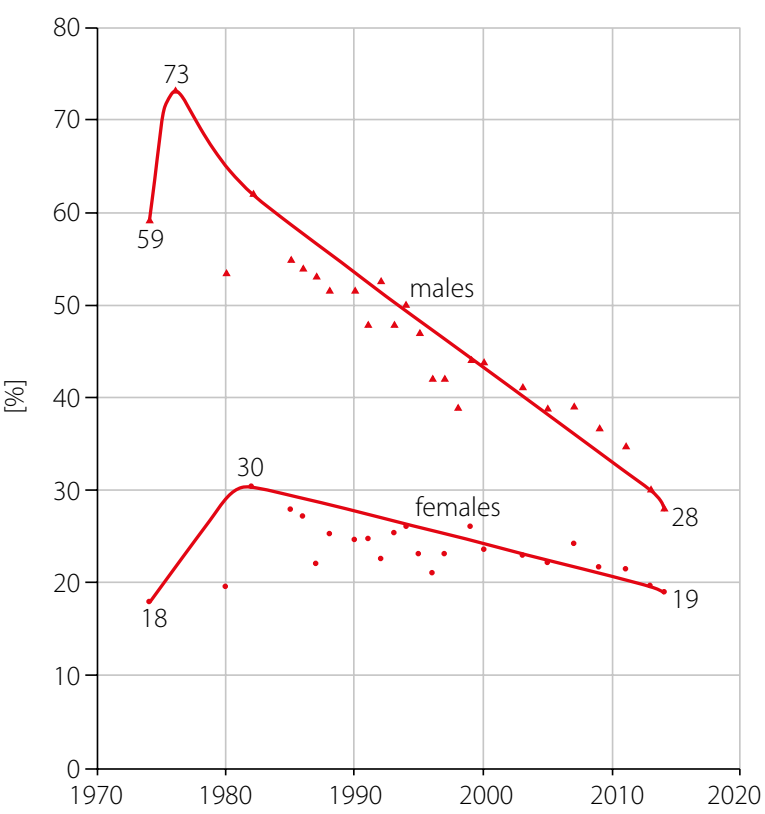

FIG. 2. Daily smoking by gender 15+, 1974-2014. Sources: [1-27]

in the world [35]. The tobacco industry became a strategic branch of the economy. In the 1980s tobacco sales stagnated due to an economic crisis brought about by political developments [12]. In 1981 cigarette rationing was introduced as a result of the shortage of consumer goods on the market. Everyone, smokers and non-smokers, received their quota of cigarettes. As a result, there was a steep rise in the number of both everyday and occasional smokers by more than one million, while the absolute number of cigarettes consumed stagnated, or even declined [9]. Prolonged exposition to tobacco smoke after several decades led to an explosion of tobacco-related diseases. Adult premature mortality (deaths in age group 15-60) belonged to the highest in the world. The probability of a 15-year-old Polish boy to die before the age of 60 was twice higher than in Western Europe, but also higher than in China and India [27, 36-37].

The third period came, unexpectedly, in the 1990s. The social attitudes towards smoking began to change and for the first time in the $20^{\text {th }}$ century cigarette consumption in Poland declined. This public health success was attributed to intervention programmes stemming from the Polish Anti-tobacco Law of 1995 [38], as well as the activity of pro-health civil society groups, the medical community, religious institutions, as well as national and local administration, in developing and conducting a comprehensive tobacco control programme $[39,40]$. According to the GBD study [41] annualised rates of change in smoking prevalence between 1990-2015 was a decrease of $1.7 \%$ in Polish men and $0.9 \%$ in Polish women, placing them among the fastest declines in the world. Among European 
countries, only Sweden, Denmark and Netherlands witnessed quicker smoking declines in males.

Overall, between 1990 and 2015 tobacco sales fell from 100 billion cigarettes to 40 billion (Fig. 1). This was accompanied by a decrease of tobacco-related diseases $[33,39]$. This positive trend continues today.

\section{CONCLUSION}

In the last years two important papers analysing the prevalence and trends of smoking in the years 1980-2012 [35] and 1990-2015 [41] have been published. Both of them ranked Poland in the top 10 countries around the world with quickest annual declines in smoking prevalence in both sexes. Between end of 1970s and 2015 the smoking prevalence in both sexes in Poland has declined by around $50 \%$. The epidemiological analysis presented in this paper documents a century of tobacco control developments in Poland.

Despite this significant progress, much still remains to be done in tobacco control in Poland. As many as $8 \mathrm{mln}$ Poles are still everyday smokers. Nonetheless, the experiences of the last decades indicated that a firm commitment to continuing the existing anti-smoking intervention programmes could help decrease premature mortality (dying before 65 years of age) in Poland by half, to under $10 \%$. This would allow Poland to catch up with Europe's public health leaders such as Sweden [42, 43].

\section{DISCLOSURE}

Authors declare no conflict of interest.

\section{References}

1. Oleś P. The extent of tobacco use in Poland. World Smok Health 1983; 8: 38-44.

2. Jokiel M. Struktura palenia tytoniu w Polsce [The structure of tobacco smoking in Poland]. Prz Epidemiol 1983; 37: 435-443.

3. Zatoński W. Częstość i rozkład palenia tytoniu w Polsce [Frequency and patterns of tobacco smoking in Poland]. Przegl Przeciwtyt 1984; 1: 136.

4. Zatoński W, Gottesman K, Przewoźniak K. Częstość palenia tytoniu w Polsce w 1985 roku [Smoking prevalence in Poland in 1985]. Zdr Publ 1988; 3: 151-156.

5. Zatoński W, Becker N. Atlas of cancer mortality in Poland 1975-1979. Springer-Verlag, Berlin 1988.

6. Przewoźniak K, Gottesman K, Kuta M, Zatoński W. Palenie tytoniu w Polsce w 1987 roku [Tobacco smoking in Poland in 1987]. Zdrowie Publ 1990; 101: 553-559.

7. Zatoński W, Przewoźniak K. Palenie tytoniu w Polsce [Tobacco smoking in Poland]. In: Zdrowotne następstwa palenia tytoniu w Polsce [Health consequences of tobacco smoking in Poland]. Ariel, Warszawa 1992.

8. Zatoński W, Przewoźniak K. Palenie tytoniu a stan zdrowia ludności w Polsce [Tobacco smoking and population health in Poland]. Prz Epidemiol 1992; 38: 53-57.

9. Przewoźniak K, Zatoński W. Tobacco smoking in Poland in the years 1923-1987. Pol Pop Rev 1993; 3:103-124.
10. Zatoński W. An overview of the challenges in tobacco problems in Central and Eastern Europe. In: Tobacco and Health. Slama K. Plenum Press, New York 1995: 281-283.

11. Zatoński W. Health status and tobacco smoking in Eastern European countries. Eur J Cancer Prev 1996; 5: 135-136.

12. Zatoński W, Przewoźniak K. Palenie tytoniu w Polsce: postawy, następstwa zdrowotne i profilaktyka [Tobacco smoking in Poland: attitudes, health consequences and prevention]. Centrum Onkologii-Instytut im. Marii Skłodowskiej-Curie, Warszawa 1996.

13. Zatoński W. The dynamics of mortality in Poland. In: Health and mortality issues of global concern. Population Division, United Nations Secretariat, New York 1999; 227-261.

14. Zatoński W, Przewoźniak K (eds.). Palenie tytoniu w Polsce: postawy, następstwa zdrowotne i profilaktyka [Tobacco smoking in Poland: attitudes, health consequences and prevention]. $2^{\text {nd }}$ ed. Centrum Onkologii-Instytut im. M. SkłodowskiejCurie, Warszawa 1999.

15. Zatoński W. Decreasing smoking in Poland: The importance of a comprehensive governmental policy. J Clin Psychiatry Monograph 2003; 18: 74-82.

16. Zatoński W. Tobacco smoking in central European countries: Poland. In: Tobacco and public health: science and policy. Boyle P, Gray N, Henningfield J, Sefrin J, Zatoński W (eds.). Oxford University Press, New York 2004: 235-252.

17. Zatoński $W$ and the HEM Project team. Closing the health gap in European Union. Cancer Center and Institute of Oncology, Warsaw 2008.

18. Zatoński W, Przewoźniak K, Sulkowska U, et al. Palenie tytoniu w populacji mężczyzn i kobiet w Polsce w latach 1974-2004 [Tobacco smoking in the population of men and women in Poland in the years 1974-2004.] Zeszyty Naukowe Ochrony Zdrowia. Zdrowie Publiczne i Zarządzanie 2009; 7: 4-11.

19. Przewoźniak K, Szlaza J, Gumkowski J, Zatoński W. Trendy codziennego palenia papierosów w Polsce w populacji kobiet w wieku prokreacyjnym w latach 1974-2004 [Trends in daily cigarette smoking among women at childbearing age, Poland 1974-2004]. Zeszyty Naukowe Ochrony Zdrowia. Zdrowie Publiczne i Zarządzanie 2009; 7: 36-43.

20. GATS Poland Collaborating Team. Global Adult Tobacco Survey (GATS) Poland 2009-2010. Ministry of Health, Warsaw 2010.

21. Zatoński W, Mańczuk M. Tobacco smoking and tobacco-related harm in the European Union with special attention to the new EU member states. In: Tobacco Science, Policy and Public Health. Second edition. Boyle P, Gray N, Henningfield J, Sefrin J, Zatoński W (eds.). Oxford University Press 2010: 221-240.

22. TNS OBOP. Walka $\mathrm{z}$ dymem tytoniowym. Komunikat $\mathrm{z}$ badań TNSOBOP K.074/10 [Fighting tobacco smoke. TNSOBOP K.074/10]. December 2010.

23. Zatoński W, Przewoźniak K, Sulkowska U, et al. Tobacco smoking in countries of the European Union. Ann Agric Environ Med 2012; 19: 181-192.

24. Giovino GA, Mirza SA, Samet JM, et al., for The GATS Collaborative Group. Tobacco use in 3 billion individuals from 16 countries: an analysis of nationally representative cross-sectional household surveys. Lancet 2012; 380: 668-679. 
25. Kachaniak D, Trząsalska A, Krassowska U. Raport z ogólnopolskiego badania ankietowego na temat postaw wobec palenia tytoniu [Report from the national survey on attitudes towards tobacco smoking in Poland]. TNS Polska, Warszawa 2015.

26. Forey B, Hamling J, Hamling J, et al. International Smoking Statistics. A collection of worldwide historical data Poland. PN Lee Statistics \& Computing Ltd, 29-Apr-2014. Available from: http://www.pnlee.co.uk/Downloads/ISS/ISS-Poland_140429. pdf (accessed: 12 November 2017).

27. Peto R, Lopez AD, Pan H, et al. Mortality from smoking in developed countries 1950-2020 (updated September 2015) Available from: http://gas.ctsu.ox.ac.uk/tobacco/index.htm (accessed: 11 February 2017).

28. Szczepański J. Badania nad wzorami konsumpcji [Studies on consumption patterns]. Ossolineum, Wrocław 1977.

29. Główny Urząd Statystyczny. Rocznik Statystyczny Rzeczypospolitej Polskiej 2016 [Central Statistical Office of Poland. Statistical Yearbook 2016]. Główny Urząd Statystyczny, Warszawa 2016.

30. Stoklosa M, Ross H. Contrasting academic and tobacco industry estimates of illicit cigarette trade: evidence from Warsaw, Poland. Tob Control 2014; 23: e30-34.

31. Ledwith F. Guidelines for the conduct of tobacco smoking surveys of the general population. Document no. WHO/ SMO/83.4. World Health Organization, Geneva 1983.

32. Global Tobacco Surveillance System Collaborating Group (Zatoński W, Przewoźniak K). Global Tobacco Surveillance System (GTSS): Purpose, Production, and Potential. J School Health 2005; 75: 15-24.

33. Zatoński WA, Tukiendorf A, and HPF team. Lung cancer mortality decline among middle-aged men and women in Poland and the UK. J Health Inequal 2017; 2: 123-126.

34. Todd GF. Cigarette consumption per adult of each sex in various countries. J Epidemiol Community 1978; 32: 289-293.

35. Ng M, Freeman MK, Fleming TD, et al. Smoking prevalence and cigarette consumption in 187 countries, 1980-2012. JAMA 2014; 311: 183-192.

36. Feachem R. Health decline in eastern Europe. Nature 1994; 367: 313-314.

37. Murray CJ, Lopez AD. Global and regional cause-of-death patterns in 1990. Bull World Health Organ 1994; 72: 447-480.

38. Ustawa $\mathrm{z}$ dnia 9 listopada 1995 r. o ochronie zdrowia przed następstwami używania tytoniu i wyrobów tytoniowych (Dz.U. z $1996 \mathrm{r}$. Nr 10 poz. 55) [Act on health protection against the consequences of consumption of tobacco and tobacco products, 1996, no 10, pos. 55].

39. Zatoński WA, Zatoński M. Poland's rapid lung cancer decline in the years 1990-2016. The first step towards the eradication of lung cancer in Poland. Health Prob Civil 2017; 11: 211-225.

40. Fagerström K, Boyle P, Kunze M, Zatoński W. The anti-smoking climate in EU countries and Poland. Lung Cancer 2001; 32 1-5.

41. GBD 2015 Tobacco Collaborators. Smoking prevalence and attributable disease burden in 195 countries and territories, 1990-2015: a systematic analysis from the Global Burden of Disease Study 2015. Lancet 2017; 389: 1885-1906.
42. Zatoński W, Bhala N. Changing trends of diseases in Eastern Europe: Closing the gap. Public Health 2012; 126: 248-252.

43. World Health Organization (WHO) Regional Office for Europe. Review of social determinants and the health divide in the WHO European Region. Final report. WHO Regional Office for Europe, UCL Institute of Health Equity 2013.

\section{AUTHORS' CONTRIBUTIONS}

WAZ prepared the concept of the publication. MZ prepared the first draft of the article. All authors contributed to preparing the final version of the text and figures. 